\title{
Innovation and competitiveness among small scale autoparts industry of Punjab, India
}

\section{B.S. SANGHA, T.P. SINGH AND AJAY BATISH}

Received : 16.05.2014; Accepted : 24.09.2014

\begin{abstract}
Innovation is a key factor for survival and sustainable growth for small scale enterprises in the competitive business environment. This paper investigates the role of regional innovation system upon the factors responsible for innovation and competitiveness among smallscale autoparts Industry. The data was collected from 110 small scale Autoparts enterprises through questionnaire cum interview schedule using single source. The study revealed that regional innovation system has a strong influence on the innovativeness of Industries through enhancement in their absorptive capacity and transfer of tacit knowledge causing incremental process innovations. Further, their existence in autoparts cluster and entrepreneurship skills of the owners were also contributing factors for the innovativeness. In addition, the research found that small scale entrepreneurs with the constrained resources of organization structure and human capital was driven to think 'low cost'; 'low tech' incremental innovations to sustain in the cut throat competition.
\end{abstract}

KEY WORDS : Small scale auto part industry, Innovation, Absorptive capacity, Regional innovation system

How to cite this paper : Sangha, B.S., Singh, T.P. and Batish, Ajay (2014). Innovation and competitiveness among small scale autoparts industry of Punjab, India. Internat. J. Com. \& Bus. Manage, 7(2) : 377-387.

\section{MEMBERS OF THE RESEARCH FORUM}

Correspondence to:

B.S. SANGHA, School of Behavioral Sciences and Business Studies, Thapar University, PATIALA (PUNJAB) INDIA

Email: balwinder_sangha@yahoo.com

Authors' affiliations:

T.P. SINGH, Symbiosis International University, PUNE (M.S.) INDIA Email: tp_malik@yahoo.com

AJAY BATISH, Thapar University, PATIALA (PUNJAB) INDIA

Email: batishajay@mail.com 